\title{
Võrdseid võimalusi ja õppimist soodustav koolijuhtimine ning koolide autonoomia
}

\author{
Pavlos Hatzopoulos $^{\text {a1 }}$, Andreas Kollias ${ }^{\text {ab }}$, Kathy Kikis-Papadakis ${ }^{\mathrm{a}}$ \\ a IACM-FORTHi haridusuuringute ja hindamise töörühm \\ ${ }^{b}$ Panteioni Ülikooli politoloogia- ja ajalooteaduskond
}

\begin{abstract}
Annotatsioon
Artikkel põhineb koolijuhtimise Euroopa võrgustiku (EPNoSL) raames tehtud tööl, eelkõige 21 Euroopa riigi koolijuhtimise strateegiate süvauuringul ja aruteludel, mis toimuvad EPNoSLi veebiseminaridel, riikide õpikodades ja vastastikuse õppe üritustel, millest võtavad osa mitmes ELi riigis koolijuhtimisega seotud huvirühmad (sh Euroopa, riikliku ja kohaliku tasandi poliitikakujundajad, koolijuhid, õpetajad ja teised haridustöötajad, õppejõud, lapsevanemad ja õpilased). EPNoSL on Euroopas tegutsevast 42 institutsioonist koosnev võrgustik, mille eesmärk on parandada Euroopa koolide juhtimist nii poliitilisel kui ka praktilisel tasandil. Artiklis käsitletakse koolide autonoomia küsimust Euroopa koolijuhtimise strateegiate kujundamise kontekstis. Koolide autonoomiat peetakse tervikliku koolijuhtimise poliitika väljatöötamise oluliseks eeltingimuseks. Artikkel tugineb kõnealuse projekti raames välja töötatud laiaulatuslikule koolijuhtimise strateegia kujundamise raamistikule ja sellel on kaks põhieesmärki. Esiteks püütakse artiklis näidata, et selle asemel et otsida koolide autonoomia puhul ühte, kõigile sobivat lahendust, tuleks keskenduda konkreetset olukorda arvestavale strateegiale, mille eesmärk on saavutada kindlaksmääratud õpitulemused ja võrdsed võimalused. Teiseks on artiklis kirjeldatud seitset koolide autonoomia põhisuunda, mida on võimalik kohandada Euroopa eripalgeliste haridussüsteemidega.
\end{abstract}

Võtmesõnad: koolijuhtimine, koolide autonoomia

\section{Sissejuhatus}

Artikkel põhineb koolijuhtimise Euroopa võrgustikus (EPNoSL) tehtud tööl. Tuginedes selle projekti raames välja töötatud laiaulatuslikule koolijuhtimise

1 Foundation for Research and Technology, Hellas Nikolaou Plastira 100, Vassilika Vouton, GR 70013 Irákleio, Kreeta, Kreeka; phatzopoulos@iacm.forth.gr 
strateegia kujundamise raamistikule, tutvustatakse artiklis mõnda olulist koolide autonoomia põhimõtetega seotud probleemi, millega on kokku puututud Euroopa eri paigus. Nende probleemide kirjeldamisel lähtutakse Euroopa riikide koolijuhtimise põhimõtetest, mida EPNoSL on viimasel kahel aastal põhjalikult arutanud ja läbi vaadanud. Meie poliitikasoovitused koolide autonoomia kohta tulenevad seega kõnealusest põhimõtete läbivaatamisest ja sama põhjalikust tutvumisest koolijuhtimise autonoomia küsimust käsitleva kirjandusega.

Sellest, kuidas mõistetakse koolijuhtimist, sõltub nii koolijuhtimise strateegia väljatöötamine ja elluviimine kui ka see, mil viisil koolieluga seotud inimesed alates kooli hoolekogust ja direktorist ning lõpetades õpetajate, lapsevanemate ja õpilastega selles osalevad. Siinses artiklis soovitatakse suhtuda koolijuhtimisse kui mitmetahulisse protsessi, milles kasutatakse strateegiliselt ära õpetajate, õpilaste ja lapsevanemate erioskusi ja teadmisi ühiste hariduseesmärkide saavutamiseks (Kollias, 2013). Küsimus on pigem suhetes kui inimestes või protsessides. Hariduseesmärkide saavutamise kontekstis tähendab see, et juhtimisega tegeletakse organisatsiooni igal tasandil, suunates peatähelepanu kõige olulisemate huvirühmade teenimisele ja innustades kogu organisatsiooni juhtimisprotsessis osalema (Hallinger \& Heck, 2010; Mulford \& Edmunds, 2009). Siinkohal mõistetakse juhtimise all olemasolevate inimressursside ning materiaalsete, sh rahaliste vahendite parimat võimalikku kasutamist. Seega tähendab kooli juhtimine dünaamilist ja ennetavat tegevust. See ei piirdu direktorite või koolijuhtidega, vaid selles osalevad ka teised haridusjuhid, näiteks kooli juhtkonna liikmed ja teised kooli visiooni mõjutavad isikud, sh õpilasomavalitsuse esindajad.

Kooli autonoomia on tervikliku koolijuhtimise strateegia kujundamise vajalik eeltingimus (Marzano, Waters, \& McNulty, 2005; OECD, 2008). Kooli juhtimist piiravad või soodustavad nii koolidele antud autonoomia ulatus kui ka sellise autonoomia võimalikud vormid erinevates haridusoludes. Selles artiklis tähendab kooli autonoomia seda, et koolidele ja kooli tasandil osalejatele on antud teatav tegevusvabadus kooli juhtimist käsitlevate otsuste tegemisel ja igapäevaste õpetamis- ja õppimisküsimuste lahendamisel ning välised (ja sisemised) piirangud piirduvad vajalike ja õiguspäraste raamistike, väärtuste ja normidega (Moos, 2013). Seetõttu peetakse kooli autonoomiat oluliseks poliitikavaldkonnaks mitte üksnes kooli tasandil õpikeskkonna kujundamise, vaid ka võrdsete võimaluste tagamise seisukohast. Haridusliku ebavõrdsuse vähendamine koolides ja koolide vahel nõuab hulgaliselt algatusi, mis heastaksid kõik erinevad koolikeskkonnas tekkivad ja korduvad diskrimineerimis- ja tõrjumisilmingud. 
Eelnevast lähtuvat arutluskäiku tutvustatakse artikli kahes järgmises jaotises. Esimeses jaotises käsitletakse koolijuhtimise kontseptsiooni. Konkreetsemalt püütakse selles näidata seoseid kooli juhtimise viisi ning koolides võrdsete võimaluste tagamise ja heade õpitulemuste saavutamise vahel. Selle ülesande täitmine on oluline, sest koolijuhtimist ja võrdseid võimalusi käsitlevas kaalukas erialakirjanduses ei tunnistata sotsiaalse õigluse struktuuripiiranguid neoliberaalses ühiskonnas (Ward et al., 2015). Nagu on väitnud Ball (2012), on koolijuhtimise kontseptsioon sageli seotud pigem tulemuste saavutamise ja n-ö numbritest lähtuva juhtimise, mitte võrdsuse tagamisega. Seda suundumust arvesse võttes on artiklis püütud koolijuhtimist käsitlevasse arutlusse lisada ka võrdsuse tagamise eesmärk. Siinkohal ei ole võrdsus seotud kõikidele ühesuguse õppekogemuse pakkumisega või isegi samade tulemuste saavutamisega kõikide rühmade puhul, olenemata nende eripärast (Lumby \& Coleman, 2007). Selle asemel et käsitada võrdsust ühetaolise kohtlemisena, on seda ehk parem mõista kui sellise olukorra loomist, kus „kõikidel lastel on võrdne võimalus valmistuda elama sellist elu, mida nad väärtustavad" (Lumby, 2013, lk 19), mis tähendab seda, et igale lapsele tagatakse just temale vajalikud vahendid - ja need ei ole kõikidel juhtudel ühesugused. Teine jaotis käsitleb konkreetselt koolide autonoomiat. Kõigepealt analüüsitakse koolide autonoomia praegust olukorda Euroopa haridussüsteemides ning seejärel tutvustatakse seitset võrdseid võimalusi ja õppimist soodustavat üldist suunda koolide autonoomia põhimõtete väljatöötamisel. Artikli lõpetab lühike kokkuvõte kõnealuse arutelu mõjust Euroopa hariduspoliitikale.

\section{Lähenemine koolijuhtimisele võrdsete võimaluste ja õppimise seisukohast}

Artiklis keskendutakse kooli juhtimisele võrdsete võimaluste ja õppimise seisukohast. Seega tuginetakse selles OECD aruandes „No more failures” kindlaks määratud kontseptuaalsele raamistikule, mille kohaselt võib võrdseid võimalusi hariduses mõista kahe omavahel tihedalt seotud mõõtme kaudu, milleks on õiglus ja kaasamine (Field, Kuczera, \& Pont, 2007). Õiglus tähendab, et õpilastel on võimalik oma hariduspotentsiaali realiseerida, ilma et seda takistaksid isiklikud või sotsiaalsed asjaolud, nagu sugu, sotsiaalmajanduslik olukord, kultuuritaust või etniline päritolu. Kaasamine tähendab miinimumtasemel baashariduse kättesaadavuse tagamist kõigile. Õppimise seisukohast lähtumine koolijuhtimisel ei hõlma üksnes õpilaste kogemuste arvestamist, vaid ka õppetegevuses osalevate erialatöötajate õpikogemuste 
arvessevõtmist. Kuna õppimine ei ole nähtav protsess, ei saa seda jälgida ega mõõta. Selles mõttes on õppimine alati seotud millegagi, mida me (veel) ei tea. Mikrotasandi (klassiruumi) ega makrotasandi (süsteemi tasandi, st PISA) testidega ei mõõdeta mitte õppimist, vaid ainult selle tulemusi (Schratz, 2013). Seepärast näitavad õpilaste tulemused üksnes seda, kuidas nad vastavad testiküsimustele, mitte ei kajasta nende õppimisvõimet. Õppimist iseloomustab kognitiivsete, emotsionaalsete ja tegevuslike protsesside tihe seotus ning seega on tegemist tervikliku inimkogemusega (Roth, 2001). Lisaks on õppimine seotud õpilase heaolu saavutamisega - seda tunnustatakse olulise tegurina, mis tundub olevat asjakohane paljude hariduseesmärkide täitmisel (Ots, 2014).

\section{Koolijuhtimine võrdsete võimaluste seisukohast}

Nagu on väitnud Lumby ja teised, nimetatakse kooli juhtimist ja haldamist käsitlevates aruteludes ebavõrdsuse püsimise põhjustena tavaliselt poliitikakujundajaid või perekondlikke/ühiskondlikke tegureid ning leitakse, et keskkond, milles kooli personal töötab, seab neile piiranguid (Begley \& Johansson, 2003; Lumby, 2013). See on aga eksitav eeldus. Koolidel ja nende töötajatel on ebavõrdsuse loomisel, säilitamisel või süvendamisel oma roll. Koolijuhid, kes püüavad kooli prioriteete ja tavasid kardinaalselt muuta, pälvivad harilikult õpetajatelt ja lapsevanematelt vaid mõõdukat toetust ja suurt vastuseisu. Näiteks võib õpetaja väita, et kui lõpetada laste jagamine võimete järgi rühmadesse, kahjustab see tema aine - või mis tahes muu aine - õpetamist. Koolijuht, kes võtab vastu ka selliseid lapsi, keda teised peavad probleemseks, riskib sellega, et lapsevanemad hakkavad tema kooli vältima. Eri riikides on täheldatud lahkumist sellistest koolidest, kus sisserändajatest õpilaste osakaal on suur. Koolijuhid puutuvad mõnikord kokku ka seisukohaga, et on lapsi, keda ei ole võimalik harida või kelle harimine on väga keeruline. Leitakse, et sisserändajate peredest pärit või rahvusvähemustesse kuuluvatel lastel on teistest enam erivajadusi, mis kajastab sügavalt juurdunud eelarvamust, mille kohaselt on erinevus seotud väiksema võimekusega. Kokkuvõttes seisavad koolijuhid silmitsi ebaõiglaste diskrimineerivate veendumustega, millele tuginevad paljude õpetajate ja lapsevanemate hinnangud selle kohta, mis on hariduses õige ja võimalik. Selliseid tõekspidamisi ja vastavat käitumist võib esineda ka koolijuhtide endi hulgas. Ebaõiglust süvendavad näiteks need koolijuhid, kes eelistavad sisseastumisel paremate saavutustega õpilasi või kes määravad kõige väiksemate kogemustega õpetajatele sellised klassid, mille õpilasi peetakse vähem võimekaks (Lumby, 2012). 


\section{Koolijuhtimine õppimise seisukohast}

Vähesed uurimistööd osutavad otsesele seosele koolijuhtide käitumise ja tavade ning õpilaste õpitulemuste või õpetajate õppimise vahel (vt nt Coelli \& Green, 2012). Leithwoodi, Seashore Louisi, Andersoni ja Wahlstromi (2004, lk 13) palju tsiteeritud ülevaates asjakohasest kirjandusest on märgitud, et „enamik juhte panustab õpilaste õppimisse kaudselt, mõjutades teisi inimesi või oma organisatsiooni eripära”. Nende väitel „sõltub juhtide panus õpilaste õppimisse seega suurel määral nende kaalutletud otsusest selle kohta, millistele oma organisatsiooni osadele aega ja tähelepanu pöörata" (ibid.). Branch, Hanushek ja Rivkin (2009, lk 18) väidavad omalt poolt, et „keeruline analüütiline probleem on mõista koolijuhtide mõju õppimisele. Koolijuhtide sihipärane määramine koolidesse ja sellest tulenevad raskused juhi panuse eristamisel kolleegide mõjust ja muudest kooliga seotud teguritest tõstatavad küsimuse selle kohta, mil määral vastutavad koolijuhid tulemuste eest”. Nende sõnul „... on põhjusel ja tagajärjel sageli üsna raske vahet teha, sest need, keda tõstetakse esile heade juhtidena, võisid lihtsalt õigel ajal õigesse kohta sattuda" (Branch, Hanushek, \& Rivkin, 2012, lk 2). Ka PISA andmete analüüsimisel ilmneb, et koolijuhtimise ja õpilaste tulemuste seose kindlakstegemine on keeruline. PISA 2009. aasta andmekogumi põhjal katsetati kahetasandilist regressioonimudelit, taandades lugemises saavutatud tulemused kõikidele õpikeskkonda ja koolikliimat (õpilaste ja kooli tasandil) käsitlevatele PISA liitindeksitele. Tulemused näitasid, et enne õpilaste ja koolide sotsiaalmajandusliku tausta arvessevõtmist olid ELi riikidest ainult Hispaanias õpilaste tulemused positiivselt seotud juhtimisindeksi suuremate väärtustega. Seevastu Slovakkia, Soome ja Itaalia puhul esines negatiivne seos (vt OECD, 2010, tabel IV.2.13b, lk 186). Pärast õpilaste ja koolide sotsiaalmajandusliku tausta arvestamist olid lugemistulemused juhtimisega (negatiivselt) seotud ainult Itaalias.

Olgugi et napib tõendeid, mis võiksid jõuliselt suunata koolijuhtimise strateegiat ja praktikat, on varasemad uurimistööd andnud väärt teadmisi, mille põhjal saab esitada koolijuhtimise kohta mitu kindlat väidet (Leithwood, Harris, \& Hopkins, 2008):

- óppimisele avalduva mõju poolest edestab koolijuhtimist ainult õpetamine klassiruumis (juhtimine toimib katalüsaatorina, mis võimaldab rakendada organisatsiooni olemasolevat võimekust);

- koolijuhid parandavad õpetamist ja õppimist kaudselt, eelkõige töötajate motivatsiooni, pühendumuse ja töötingimuste mõjutamise kaudu. 


\section{Koolide autonoomia kui suurt poliitilist tähelepanu vajav valdkond}

Koolide autonoomia on olnud suurema osa ELi riikide haridusreformide keskmes alates 1980. aastatest. Kuigi autonoomia elluviimisel esineb Euroopa valitsuste vahel väga suuri erinevusi (peamiselt seoses ajakava, võimaldatava autonoomia taseme ja ulatusega ning viisiga, kuidas koolide autonoomia on seotud aruandlussüsteemide ning riiklike või piirkondlike raamistike ja normide kehtestamisega), on teadlased ja poliitikud saavutamas üha suuremat üksmeelt selles, et koolide autonoomia on õpitulemuste parandamisel määrava tähtsusega tegur (Eurydice, 2007). Eelkõige ollakse üksmeelel selles, et koolijuhtidel on prioriteetne roll kooli igapäevast ja pikaajalist haldamist käsitlevate oluliste otsuste tegemisel (OECD, 2008). Teiselt poolt on paljudes riikides suurendatud keskasutuste mõju normide, õppekavade ja hindamissüsteemide kehtestamisele (OECD, 2012).

Eurydice võrgustiku hiljutise aruande kohaselt näib, et ELi koolisüsteemides on koolidel suur autonoomia õpetamismeetodite, õpikute ning õpilaste hindamise meetodite ja valikainete õppekava sisu valimisel ning õpilaste jagamisel rühmadesse õppetegevuse eesmärgil. Selge erand on Kreeka, kus sellised küsimused otsustab peamiselt haridusamet (v.a õpilaste jagamine rühmadesse) (vt Eurydice, 2013). Eurydice andmetel jäetakse kõikides ELi riikides õpetamismeetodid põhi- ja keskkoolides õpetajate ja/või koolijuhtide / kooli hoolekogude otsustada. Kõikide ELi koolisüsteemide puhul, mida Eurydice jälgib, kehtib sama ka õpikute, hindamismeetodite, õpilaste rühmadesse jagamise ja valikainete õppekava sisu kohta. Peale Kreeka kuuluvad õpikutega seotud otsused haridusametite pädevusse ka Küprosel ja Maltal, seevastu Prantsusmaal otsustavad haridusametid valikainete õppekava sisu ning Portugalis ja Slovakkias õpilaste jagamise rühmadesse õppetegevuse eesmärgil. Põhi- ja keskkoolide töötajate ja inimressurssidega seotud otsused teevad enamikus ELi koolisüsteemides koolijuhid või kooli juhtkond kooli tasandil. Üldiselt tundub, et Kreeka, Prantsusmaa ja Küprose koolid ei saa teha autonoomseid otsuseid õpetajate töölevõtmise, puuduvate õpetajate asendajate valimise, õpetajate töölt vabastamise, õpetajate kohustuste ja vastutusalade ega koolijuhi valimise kohta. Kõikide nende küsimuste eest vastutavad haridusametid. Itaalia koolid saavad teha otsuseid üksnes õpetajate kohustuste ja vastutusalade kohta ja Malta koolid asendusõpetajate valiku kohta (ibid.).

OECD 2012. aasta aruandes „Education at a glance 2012” osutatakse koolide autonoomia põhimõtete olulistele erinevustele Euroopas. OECDINESi 2011. aasta uuringust otsustustasandi kohta 2010/2011. óppeaastal 
ilmneb, et riiklikud põhikoolid teevad üle poole otsustest täiesti autonoomselt ainult kümnes riigis/piirkonnas (NL, $\mathrm{UK}_{\mathrm{EN}}, \mathrm{SI}, \mathrm{EE}, \mathrm{CZ}, \mathrm{BE} \mathrm{FL}, \mathrm{SK}, \mathrm{HU}$, SI ja IE), samas kui ainult neljas neist (NL, $\left.\mathrm{UK}_{\mathrm{EN}}, \mathrm{EE}, \mathrm{BE}_{\mathrm{FL}}\right)$ tehakse kooli tasandil üle 70\% otsustest. 13 riigis/piirkonnas teevad riiklikud põhikoolid täiesti autonoomselt alla poole otsustest $\left(\mathrm{UK}_{\mathrm{SC}}, \mathrm{SE}, \mathrm{DK}, \mathrm{PL}, \mathrm{IT}, \mathrm{ES}, \mathrm{AT}\right.$, $\mathrm{BE}_{\mathrm{FR}}$, DE, ES, PT, LU, EL) ning viies neist (DE, ES, PT, LU, EL) tehakse kooli tasandil vähem kui veerand otsustest (OECD, 2012).

Mitmes ELi koolisüsteemis vähenes aastatel 2003-2011 nende otsuste osakaal, mis tehti óppetöö korralduse kohta kooli tasandil (põhikooli III aste) ${ }^{2}$. Näiteks vähenes Ungari ülemise astme põhikoolides (vt vasakpoolne diagramm allpool) ajavahemikul 2007-2011 kooli tasandil õppetööga seotud küsimustes tehtavate otsuste osakaal 22\% (100\%-lt 78\%-ni) - otsuste tegemine läks üle kohaliku ja kesktasandi haridusametitele. Sama suundumus esines Portugalis (75\%-lt 2003. aastal 56\%-ni; otsuste tegemine läks üle kesktasandile), Luksemburgis (63\%-lt 44\%-ni; läks üle kesktasandile), Slovakkias (88\%-lt 75\%-ni; läks üle kesktasandile), Itaalias (100\%-lt 89\%ni; läks üle kesktasandile) ja Inglismaal (100\%-lt 89\%-ni; läks üle kohalikule tasandile). Õppetöö korralduse kohta kooli tasandil tehtavate otsuste osakaalu märkimisväärset kasvu täheldati ainult kahes põhikooli ülemises astmes Tšehhi Vabariigis ja Eestis (88\%-lt 100\%-ni). Üldiselt tundub, et paljudes ELi ülemise astme põhiharidussüsteemides on haridusreformid viimase kümnendi jooksul koolide autonoomiat õppetöö küsimustes vähendanud.

Nagu ilmneb joonistelt 1, 2, 3 ja 4, anti aastatel 2003-2011 tehtud reformidega otsustusõigus personalijuhtimise, kavandamise ja struktuuride ning ressursside valdkonnas koolidelt üle kõrgematele otsustustasanditele (eelkõige kesktasandile) mitmes ELi ülemise astme põhiharidussüsteemis, mida OECD jälgib. Need järeldused näitavad, et kuigi poliitikaalastes aruteludes pööratakse üha suuremat tähelepanu juhtimise edendamisele koolides, on reformid piiranud paljudes ELi koolisüsteemides koolide tegevusvabadust mitmesugustes otsuste tegemise valdkondades, millest kõige olulisem on õppetöö korraldus.

2 Allikas: OECD, 2012, tabel D6.6a (ainult veebis). Kättesaadav aadressil http://dx.doi.org/10.1787/888932668489. 


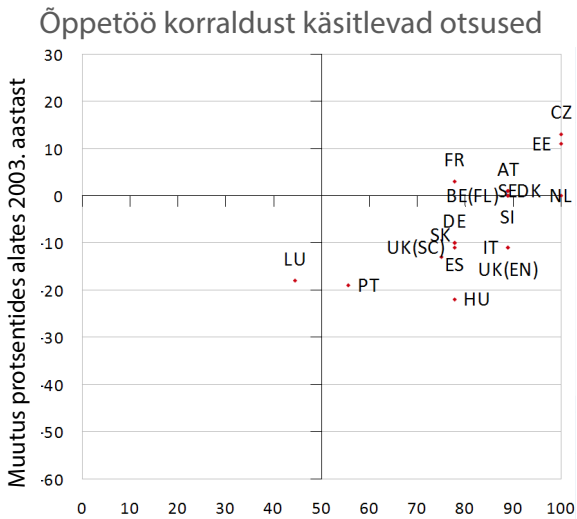

Õppetöö korralduse kohta kooli tasandil tehtavate otsuste osakaal 2011. aastal riikliku pöhihariduse III astmes

* Sloveenia puhul on võrdlusaasta 2007. aasta.

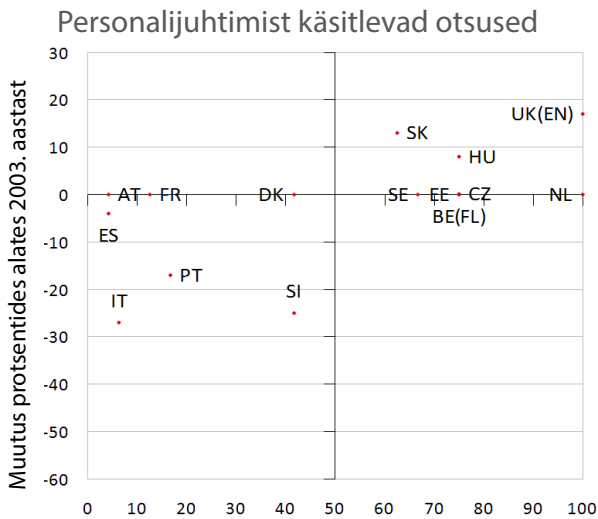

Personalijuhtimise kohta kooli tasandil tehtavate otsuste osakaal 2011. aastal riikliku põhihariduse III astmes

* Sloveenia puhul on võrdlusaasta 2007. aasta.

\section{Kavandamist ja struktuure käsitlevad otsused}

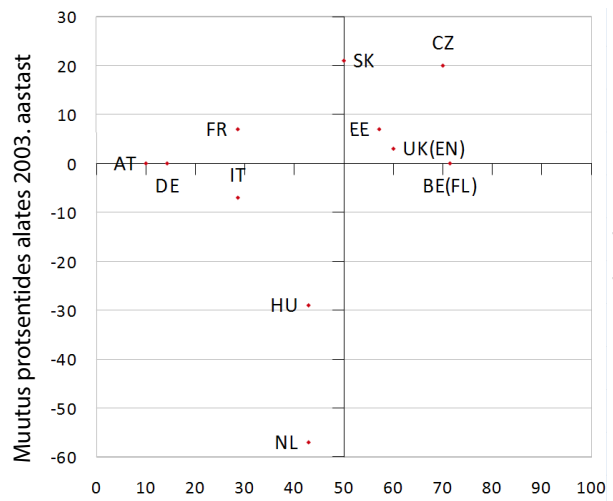

Kavandamise ja struktuuride kohta kooli tasandil tehtavate otsuste osakaal 2011. aastal riikliku põhihariduse III astmes

* Eesti ja Šotimaa puhul on võrdlusaasta 2007. aasta.

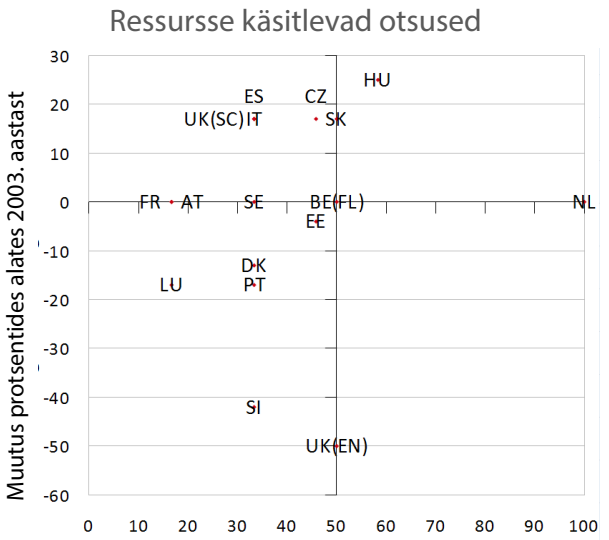

Ressursside kohta kooli tasandil tehtavate otsuste osakaal 2011. aastal riikliku põhihariduse III astmes

* Belgia (Flaami piirkond), Eesti ja Šotimaa puhul on võrdlusaasta 2007. aasta.

Joonised 1, 2, 3 ja 4. Avalikus ülemise astme põhihariduses kooli tasandil tehtavate otsuste osakaal 2011. aastal võrreldes 2003. aastaga (allikas: OECD) 3

Teine koolide autonoomiat käsitlevate andmete allikas on OECD 2009. aasta PISA uuring. PISA andmed erinevad eespool kirjeldatud OECD-INESi 2011. aasta otsustustasandi uuringu andmetest ja Eurydice andmetest

3 Sealsamas, andmed pärinevad tabelitest D6.6a-D6.6d. MÄRKUS: nende koolisüsteemide puhul, mis jäävad eespool esitatud diagrammide ülemisse ossa, oli nende otsuste osakaal, mida koolid saavad asjaomases valdkonnas teha, 2011. aastaks võrreldes 2003. aastaga kasvanud, samas kui alumisse ossa jäävate süsteemide puhul oli see vähenenud. Koolide suuremat autonoomiat lubavad süsteemid on esitatud diagrammil paremal, väiksemat autonoomiat võimaldavad süsteemid vasakul. 
kvalitatiivselt selle poolest, et viimased andmed saadi ekspertidelt, kuid esimesed koguti tuhandete PISA testides osalenud koolide juhtidelt. PISA uuringu tulemused koolide autonoomia kohta õppekava ja hindamist käsitlevate otsuste tegemisel on esitatud järgmisel diagrammil.

Nagu ilmneb jooniselt 5, ei otsustata sellistes riikides nagu Madalmaad, Tšehhi Vabariik, Ühendkuningriik, Eesti, Slovakkia, Leedu, Soome, Poola, Sloveenia ja Rootsi õppekava ja hindamismeetodite üle eranditult riigi või piirkondlikul tasandil ning koolidel on nendes küsimustes kas täielik autonoomia või teevad nad selliseid otsuseid koostöös haridusametitega. Seevastu sellistes riikides nagu Kreeka (EL), Portugal, Bulgaaria ja Horvaatia on määrav roll piirkondlikel või riiklikel ametiasutustel ja koole kaasatakse otsustusprotsessi vähesel määral.

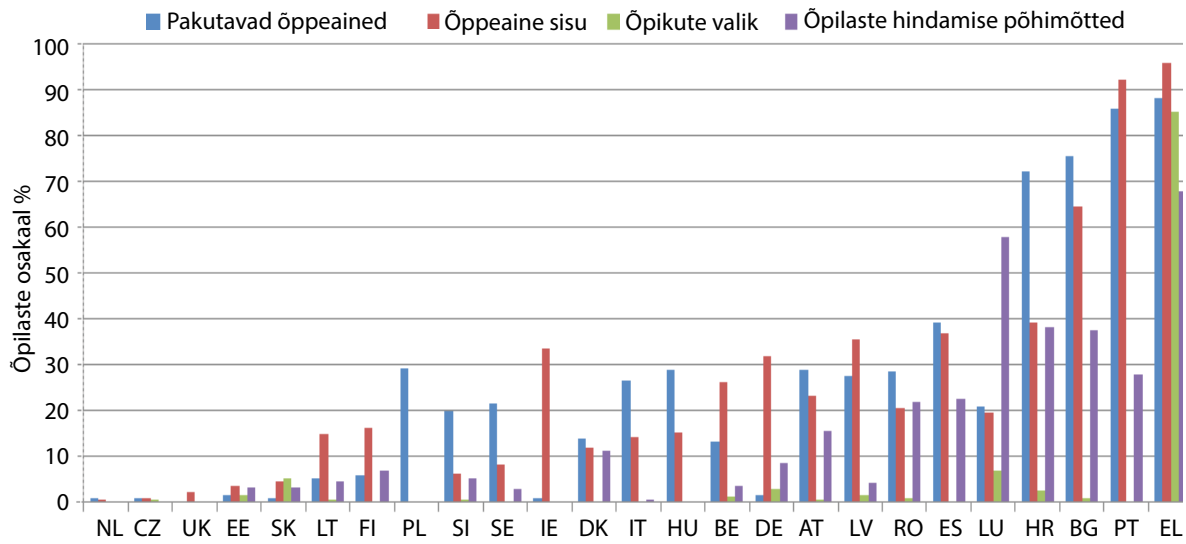

Joonis 5. Õpilaste osakaal koolides, mille direktorid märkisid, et oluline vastutus õppeainete ja nende sisu, õpikute ja hindamispõhimõtete eest lasub üksnes „piirkondlikul ja/või riiklikul haridusametil" (allikas: OECD, PISA 2009. aasta uuringu andmebaas, tabel IV.3.6)

Jooniselt 6 selgub, et enam kui pooltes ELi riikides tehakse õpetajate töölevõtmise ja töölt vabastamise otsused kooli tasandil või koostöös ametiasutustega. Seevastu enamikus ELi riikides määravad piirkondlikud või riiklikud ametiasutused kindlaks õpetajate palgad. Koolid saavad selles küsimuses kaasa rääkida vaid üksikutes ELi riikides, nagu Bulgaaria, Tšehhi Vabariik, Madalmaad, Ühendkuningriik ja Rootsi (vt joonis 7). Ent koolidel on suurem vabadus oma eelarve koostamisel ja haldamisel, seda isegi ELi kõige tsentraliseeritumates riikides, nagu Kreeka, Rumeenia, Itaalia või Portugal (vt joonis 8). 


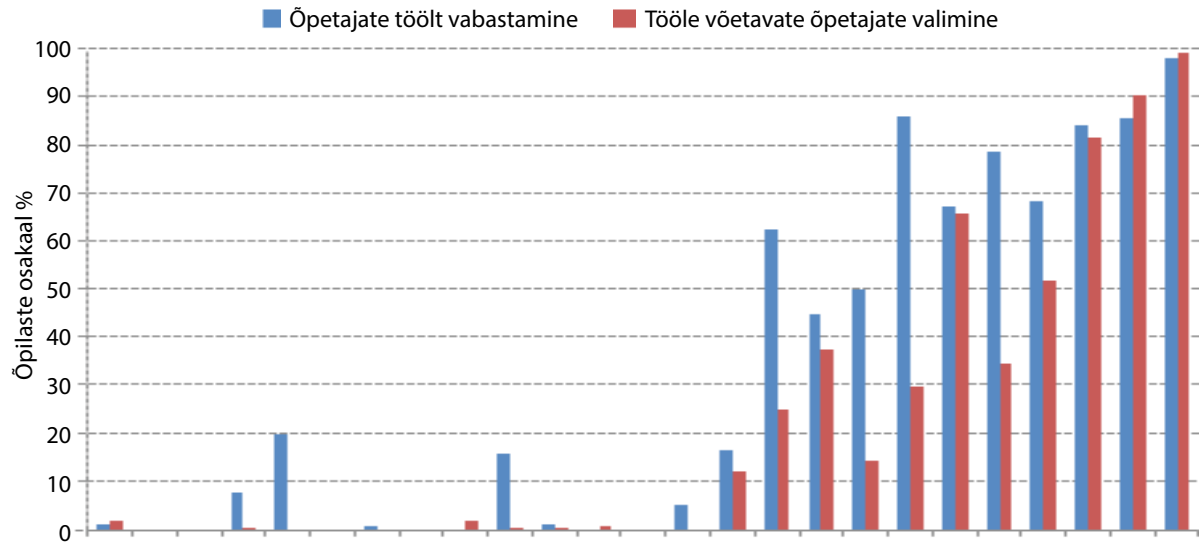

RG CZ NL UK SE SK HU EE LV DK SI PL LT HR
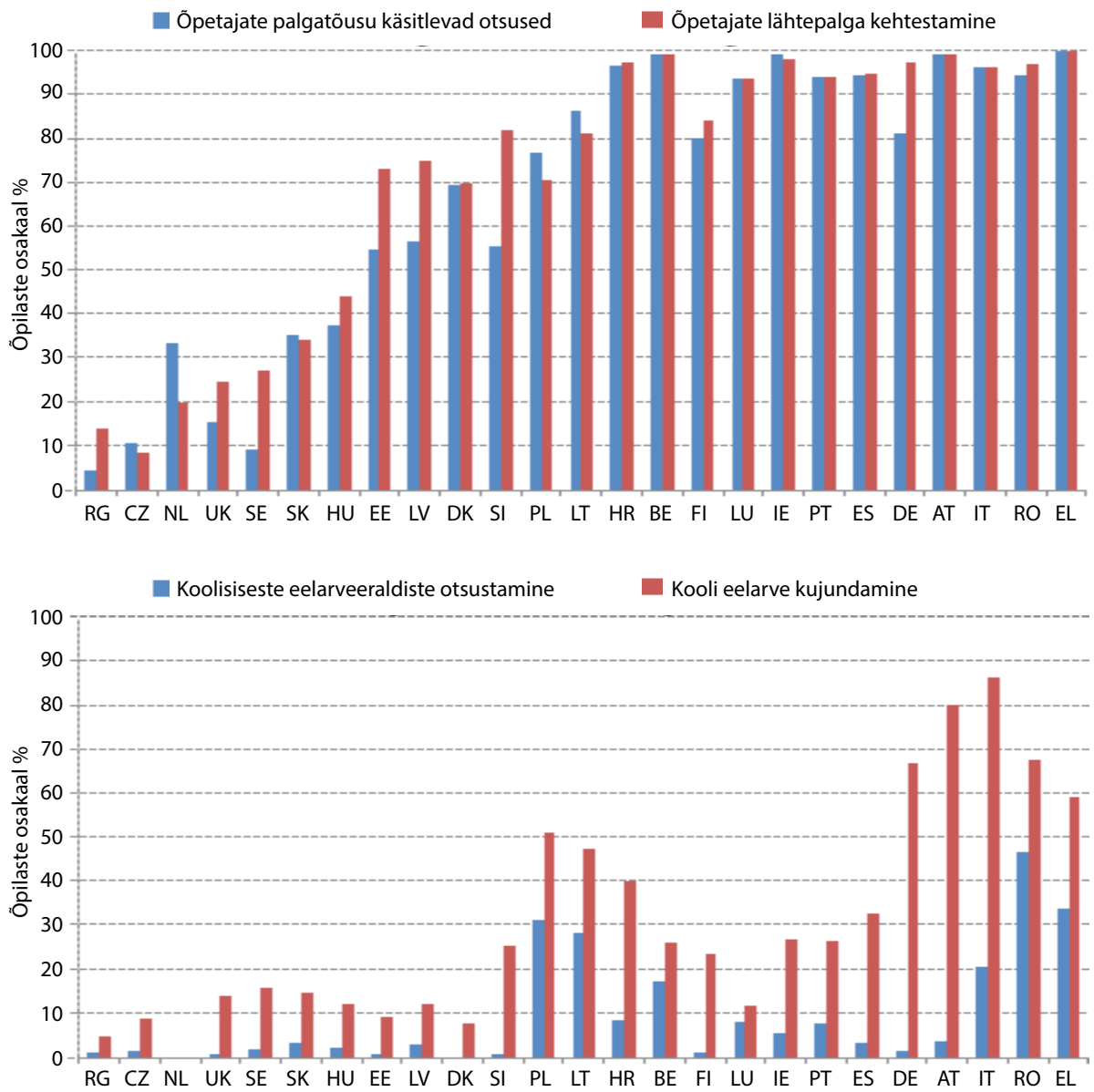

Joonised 6, 7 ja 8. Õpilaste osakaal koolides, mille direktorid märkisid, et oluline vastutus ressursside eraldamise eest lasub üksnes „piirkondlikul ja/või riiklikul haridusametil" (allikas: OECD, PISA 2009. aasta uuringu andmebaas, tabel IV.3.5) 
PISA 2009. aasta uuringu andmete analüüsi põhijäreldus koolide autonoomia kohta on see, et nende koolisüsteemide puhul, kus koolidele on antud õppekava ja hindamist käsitlevate otsuste tegemisel suurem autonoomia (piirates samal ajal koolidevahelist konkurentsi), on tulemused tõenäoliselt OECD keskmisest paremad ja õpilaste sotsiaalmajandusliku tausta mõju nende tulemustele on keskmisest väiksem (OECD, 2010). Silmapaistvad näited on Soome, Madalmaad ja Eesti, kus koolidel on eriti õppetöö korralduse küsimustes suur autonoomia ning mis saavutasid PISA 2009. aasta uuringus väga häid tulemusi, samal ajal on seal nõrk seos õpilaste tulemuste ja nende sotsiaalmajandusliku tausta vahel.

\section{Mitmesugused poliitikaraamistikud, mis suurendaksid koolide autonoomiat}

Kuna praegu on Euroopa koolide autonoomia tase, vormid ja määratlused niivõrd erinevad, ei saa kaaluda selles valdkonnas ühise üleeuroopalise poliitika rakendamist. Poliitika kujundamise seisukohast on koolide autonoomia puhul ühe, kõigile sobiva lahenduse otsimise asemel oluline keskenduda kontekstist lähtuvale poliitikale, mis oleks suunatud konkreetsete õppimise ja võrdsete võimalustega seotud eesmärkide saavutamisele.

Allpool on tutvustatud seitset koolide autonoomiat käsitleva poliitika üldsuunda, mida on võimalik kohandada Euroopas kehtivate haridussüsteemidega. Need poliitikasuunad ei ole üheülbalised, vaid on koostatud selleks, et teavitada mitmesuguseid hariduskeskkondi valdkondadeülestest poliitilistest kaalutlustest, mille kaudu on võimalik autonoomiat käsitleda. Need põhinevad EPNoSLi projekti raames tehtud tööl, sealhulgas koolide autonoomiaalase kirjanduse põhjalikul läbivaatamisel, EPNoSLi sise- ja välisekspertide panusel, EPNoSLi partnerite uurimistöödel, EPNoSLi veebiseminaridel ja foorumitel, riikide õpikodade tegevusel ning aruteludel, mis on toimunud viimase kahe aasta jooksul mitmes ELi riigis korraldatud vastastikuse õppe üritustel.

1. Koolide autonoomiat käsitlevas poliitikas tuleks täpsustada, millistes otsusvaldkondades tuleks koolide autonoomiat laiendada (või kitsendada), mis eesmärgil autonoomia antakse ning millised peaksid olema sobilikud mehhanismid (aruandlussüsteemid, üldised raamistikud, normid), mille kaudu koolide autonoomiat kontrollitakse või tasakaalustatakse. Olenevalt sellest, millised on vastused neile küsimustele, peavad poliitikakujundajad üldpõhimõttena tagama, et koolide autonoomiat käsitlev poliitika aitaks ka tegelikult luua soodsat koolijuhtimise keskkonda, mille aluseks on usaldus koolijuhtide professionaalsuse vastu ja vastastikune mõistmine. 
2. Poliitika, millega antakse koolidele suurem autonoomia ja soodustatakse samal ajal ülereguleeritud, bürokraatlikku ja lämmatavat aruandlussüsteemi, võib kahjustada koolijuhtide tegelikku tegutsemisvabadust võrdsete võimaluste ja óppimise edendamisel koolides. See tuleneb asjaolust, et koolijuhid võivad olla sunnitud kulutama hierarhias kõrgemal asuvatele haridusametitele aruannete esitamiseks või haldusülesannete täitmiseks rohkem aega kui õppetöö ja koolielu kui terviku korraldamiseks, et edendada võrdseid võimalusi ja õppimist.

3. Koolide autonoomiat käsitlev poliitika peaks sisaldama prioriteete hariduse andmisel esineva ebavõrdsuse vastu võitlemiseks kohapeal. Koolide autonoomia on võrdsete võimaluste saavutamisel määrava tähtsusega poliitikameede, sest haridusalase ebavõrdsuse vähendamine koolides ja koolide vahel nõuab mitmeid algatusi, mis heastaksid kõik erinevad koolikeskkonnas tekkivad ja korduvad diskrimineerimis- ja tõrjumisilmingud.

4. Koolide autonoomiat laiendava poliitika üheks tagajärjeks on see, et koolijuhtide töö muutub pingelisemaks ja keerulisemaks. Seepärast peaks reformidega, millega antakse kooli tasandile suurem otsustusõigus, kaasnema ka koolijuhtidele suunatud kutsearengu võimaluste pakkumine ja tulevasi koolijuhte ettevalmistavate programmide õppekavade muutmine.

5. Suurem autonoomia mõjutab koolijuhtide töökoormust. Kooli juhtimisega seotud ülesannete ja kohustuste ulatuslikum delegeerimine on üks oluline võimalus, mis võib aidata koolijuhtidel paisunud töökoormusega tõhusamalt toime tulla. Rutiinsed haldusülesanded võib anda üle abipersonalile, et koolijuhtidele jääks rohkem aega õppimise ja võrdsete võimalustega tihedalt seotud küsimustega tegelemiseks. Seoses koolide autonoomia laiendamise poliitikaga tuleks kaaluda ka meetmeid, mis pakuksid juba töötavatele ja potentsiaalsetele koolijuhtidele atraktiivseid stiimuleid.

6. Sellistes haridussüsteemides, kus koolidel on suhteliselt väike autonoomia võrdsete võimaluste ja õppimisega otseselt seotud vajalike otsuste tegemisel nt pedagoogika, õppesisu ja hindamismeetodite valdkonnas, on veelgi pakilisem vajadus kaaluda üksteist täiendavate reformide elluviimist. Näiteks peaksid Kreeka, Luksemburgi ja Slovakkia poliitikakujundajad kaaluma võimalust anda koolidele suurem autonoomia õpikute valimisel ja õppetöö aega käsitlevate otsuste tegemisel. Mitme ELi koolisüsteemi puhul peaksid poliitikakujundajad kaaluma ka reforme, mis annaksid koolidele suuremad volitused mõjutada oma koolis õpetatavate ainete valikut ja õppeaine sisu käsitlevaid otsuseid (nt Austrias, Taanis, Kreekas, Iirimaal, Luksemburgis ja Hispaanias). Samuti tuleks suurendada koolide võimalust mõjutada otsuseid, mis puudutavad koolijuhtide ja õpetajate kutsealaseks arendamiseks eraldatavaid ressursse (nt Austrias, Belgias, Kreekas, Iirimaal, Itaalias, Portugalis ja Hispaanias). 
7. Koolidele suuremat autonoomiat andvate reformide kehtestamise tempo on oluline tegur reformide rakendamisel. Eelkõige sellistes süsteemides, kus otsuseid on tehtud pikka aega tsentraliseeritult ja koolide autonoomia on olnud suhteliselt piiratud, tuleks koolide juhtimises teha muutusi järkjärgult, et suurendada koolide suutlikkust oma uute ülesannete ja kohustustega toimetulekul.

\section{Kokkuvõte}

Artiklis käsitleti koolide autonoomia küsimust Euroopa koolijuhtimise poliitika kujundamise kontekstis. Koolide autonoomiaga seotud küsimuste arutamine koolijuhtimise strateegia seisukohast võib olla kasulik, kui on võimalik esitada asjakohaseid küsimusi selle kohta, kas koolide autonoomia on teatavas haridussüsteemis soovitav ning mis tingimustel ja eesmärgil tuleks see koolidele anda. Seetõttu püüti artiklis kirjeldada raamistikku, mille puhul hõlmab poliitika võrdsete võimaluste ja õppimisega seotud eesmärke, pidades silmas paindlikkust ja autonoomiat, mida vajaksid koolijuhid nende kooli puudutavate oluliste otsuste tegemisel.

Samas tuleb olla hoolikas, et mitte käsitleda koolide autonoomia küsimust lahus konkreetses haridussüsteemis rakendatava hariduspoliitika laiemast kontekstist (Lauri, 2014; Türk et al., 2011). Keskvalitsuse poliitilised otsused loovad harilikult uue olukorra, mis omakorda tekitab uusi probleeme poliitika kujundamisel. Näiteks võib koolide autonoomiat suurendav keskvalitsuse poliitika luua soodsa pinnase koolijuhtimise arenguks, ent koolide laiem autonoomia tekitab poliitika kujundamisel omakorda uusi probleeme seoses keskvalitsuse võimalustega tagada, et koolijuhid vastutavad oma otsuste eest ise.

Euroopa riigid saavad koolide autonoomia poliitikale läheneda mitmel viisil. Näiteks peavad tsentraliseeritumate koolisüsteemidega ELi liikmesriigid, nagu Prantsusmaa ja Kreeka, tõenäoliselt kaaluma teistsuguseid lahendusi kui ülimalt detsentraliseeritud koolisüsteemidega liikmesriigid, nagu Rootsi, Soome ja Madalmaad, või liikmesriigid, kus on mitu koolisüsteemi, nagu Ühendkuningriik, Saksamaa või Belgia. Peale selle tuleb nendel ELi liikmesriikidel, keda majanduskriis tugevalt mõjutas ja kes on kooliharidusse tehtavaid avalikke kulutusi oluliselt vähendanud, kaaluda rahaliste vahendite kättesaadavuse vähenemise tõttu tõhusamaid lahendusi kui sellistel ELi liikmesriikidel, kes on kriisiga hästi toime tulnud ning kelle avalikud kulutused kooliharidusele on püsinud samal tasemel või isegi suurenenud. 


\section{Kasutatud kirjandus}

Ball, S. J. (2012). Global Education Inc.: New policy networks and the neo-liberal imaginary. Abingdon: Routledge.

Begley, P. T., \& Johansson, O. (Eds.) (2003). The ethical dimensions of school leadership. London: Kluwer Academic Publishers. doi: http://dx.doi.org/10.1007/0-306-48203-7

Branch, G. F., Hanushek, E. A., \& Rivkin, S. G. (2009). Estimating principal effectiveness. Washington: CALDER. Retrieved from

http://www.urban.org/uploadedpdf/1001439-Estimating-Principal-Effectiveness.pdf.

Branch, G. F., Hanushek, E. A., \& Rivkin, S. G. (2012). Estimating the effect of leaders on public sector productivity: The case of school principals. CALDER Working Paper No. 66. Retrieved from http://www.nber.org/papers/w17803.pdf.

Coelli, M., \& Green, D. A. (2012). Leadership effects: School principals and student outcomes. Economics of Education Review, 31(1), 92-109.

doi: http://dx.doi.org/10.1016/j.econedurev.2011.09.001

Eurydice (2007). School autonomy in Europe. Policies and measures. Eurydice thematic report. Luxembourg: Publications Office of the European Union. Retrieved from http://eacea.ec.europa.eu/education/eurydice/documents/thematic_reports/090EN.pdf.

Eurydice (2013). Key data on teachers and school leaders in Europe. 2013 Edition. Eurydice report. Luxembourg: Publications Office of the European Union. Retrieved from http://eacea.ec.europa.eu/education/eurydice/documents/key_data_series/151EN.pdf.

Field, S., Kuczera, M., \& Pont, B. (2007). No more failures: Ten steps to equity in education. Paris: OECD Publishing. doi: http://dx.doi.org/10.1787/9789264032606-en

Hallinger, P., \& Heck, R. H. (2010). Collaborative leadership and school improvement: Understanding the impact on school capacity and student learning. School Leadership and Management, 30(2), 95-110. doi: http://dx.doi.org/10.1080/13632431003663214

Kollias, A. (Ed.) (2013). Critical factors in the discourse on school leadership from the perspective of equity and learning. EPNoSL Project. Retrieved from

http://www.schoolleadership.eu/sites/default/files/epnosl-del-2.1-2013_1.pdf.

Lauri, T. (2014). Lõimiv koolivalik kui võimalus avalikkuse taastootmiseks kaasaegses haridusvalitsetuses. Acta Politica Estica, 5, 20-41.

Leithwood, K., Harris, A., \& Hopkins, D. (2008). Seven strong claims about successful school leadership. School Leadership \& Management, 28(1), 27-42. doi: http://dx.doi.org/10.1080/13632430701800060

Leithwood, K., Seashore Louis, K., Anderson, S., \& Wahlstrom, K. (2004). Review of research: How leadership influences student learning. The Wallace Foundation. Retrieved from http://www.wallacefoundation.org/knowledge-center/school-leadership/key-research/Documents/How-Leadership-Influences-Student-Learning.pdf.

Lumby, J. (2012). Disengaged and disaffected young people: Surviving the system. British Educational Research Journal, 38(2), 261-279. doi: http://dx.doi.org/10.1080/01411926.2010.541553

Lumby, J. (2013). Longstanding challenges, new contexts: Leadership for equality. International Studies in Educational Administration, 40(3), 17-38.

Lumby, J., \& Coleman, M. (2007). Leadership and diversity: Challenging theory and practice in education. London: Sage. 
Marzano, R. J., Waters, T., \& McNulty, B. A. (2005). School leadership that works: From research to results. Alexandria: Association for Supervision and Curriculum Development (ASCD).

Moos, L. (2013). Diverse perspectives and hopes on autonomy in school leadership. In A. Kollias (Ed.), Critical factors in the discourse on school leadership from the perspective of equity and learning (pp. 35-38). EPNoSL Project.

Mulford, B., \& Edmunds, B. (2009). Successful school principalship in Tasmania. Launceston: University of Tasmania.

OECD (2008). Improving school leadership. Volume 1: Policy and practice, Volume 2: Case studies on system leadership. Paris: OECD. Retrieved from http://www.oecd.org/education/school/improvingschoolleadership-home.htm.

OECD (2010). PISA 2009 results: What makes a school successful? Resources, policies and practices (Vol. 4). Retrieved from http://dx.doi.org/10.1787/9789264091559-en.

OECD (2012). Education at a glance 2012: OECD indicators. OECD Publishing. Retrieved from http://dx.doi.org/10.1787/eag-2012-en.

Ots, A. (2014). Õpilaste heaolu resilientsus ja mõistestruktuuri areng: erinevused kooliga rahulolu säilitamisel ebameeldivate koolikogemuste ja klassiõpetaja kasvatusstiili taustal. Eesti Haridusteaduste Ajakiri, 2(1), 132-161. doi: http://dx.doi.org/10.12697/eha.2014.2.1.06

Roth, G. (2001). Fühlen, Denken, Handeln. Wie das Gehirn unser Verhalten steuert. Frankfurt: Suhrkamp.

Schratz, M. (2013). Beyond the reach of leading: Exploring the realm of leadership and learning. EPNoSL Keynote Article. Retrieved from http://www.schoolleadership.eu/sites/default/files/leadership-for-learning-2013.pdf.

Türk, K., Haldma, T., Kukemelk, H., Ploom, K., Irs, R., \& Pukkonen, L. (2011). Üldharidus- ja kutsekoolide tulemuslikkus ja seda mõjutavad tegurid. Tartu Ülikool, Haridus- ja Teadusministeerium. Külastatud aadressil https://www.riigikantselei.ee/ valitsus/valitsus/et/KooliTulemusjuhtimine2011\%5B1\%5D.pdf.

Ward, S. C., Bagley, C., Lumby, J., Woods, P., Hamilton, T., \& Roberts, A. (2015). School leadership for equity: Lessons from the literature. International Journal of Inclusive Education, 19(4), 333-346. doi: http://dx.doi.org/10.1080/13603116.2014.930520 